\title{
REEVALUATING THE ROLE OF TRADE AGREEMENTS: \\ DoEs InVESTMENT GLOBALIZATION MAKE THE WTO OBSOLETE?
}

\author{
EMILY J. BLANCHARD \\ CESIFO WORKING PAPER NO. 1735 \\ CATEgORY 7: TRAde POLICY \\ MAY 2006
}

Presented at CESifo Area Conference on Global Economy, April 2006

An electronic version of the paper may be downloaded

- from the SSRN website:

- from the RePEc website:

www.SSRN.com

- from the CESifo website:

www.RePEc.org

www.CESifo-group.de 


\title{
REEVALUATING THE Role OF TRADE AGREEMENTS: DOES INVESTMENT GLOBALIZATION MAKE THE WTO OBSOLETE?
}

\begin{abstract}
This paper demonstrates that international ownership can mitigate the terms of trade externalities that lead large countries to set inefficiently high tariffs, and may thereby substitute for negotiated tariff liberalization in eliminating the strategic manipulation of world prices. The policy prediction is unclear, however, since international cross-ownership also introduces an internal cost-shifting externality that can drive investment-host countries to expand local market access beyond efficient levels in an effort to extract rents from foreign investors. An immediate implication is that simply making large countries "act small" or completely diversify their global investment portfolios to neutralize traditionally understood terms of trade cost-shifting motives cannot ensure efficient trade policy regimes in an environment with international investment. At the same time, a modified version of the principle of reciprocity does continue to serve as an important guide to efficiency by balancing countries' external and internal pecuniary externalities.
\end{abstract}

JEL Code: F01, F13, F15, F21.

\author{
Emily J. Blanchard \\ Department of Economics \\ University of Virginia \\ P.O. Box 400182 \\ Charlottesville, VA 22904-4182 \\ USA \\ blanchard@virginia.edu
}

April 2006

Thoughtful comments from Robert Baldwin, Charles Engel, Amy Glass, Linda Goldberg, Chia-Hui Lu, John McLaren, Scott Taylor, Camilo Tovar, Eric van Wincoop, and seminar participants at CES Ifo, CeMENT 2006, Georgetown University, the University of Virginia, and the University of Wisconsin have improved this paper considerably. I am particularly grateful to Bob Staiger for guidance and support. Funding from the Bankard Fund for Political Economy is gratefully acknowledged. 


\section{Overview}

A common caveat overshadows much of the debate about the role of negotiated tariff liberalization as a solution to a terms of trade driven prisoners' dilemma: standard models cannot address the potential for international investment to influence governments' preferences over trade policies. It seems likely that an us-versus-them mercantilist framework for understanding the governance of international market access may be incomplete in an age when countries' entrepreneurial interests extend beyond their own borders and locally operated enterprizes are not necessarily locally owned.

The common trait across virtually all forms of cross-border investment - whether the acquisition of domestic firms by foreign interests, foreign direct investment (FDI), multinationals' foreign affiliate activities, international portfolio diversification, or cross-country mergers - is that the pattern of international ownership is divorced from countries' domestic production portfolios. The critical implication is that international investment - however broadly defined - constitutes non-trade economic integration across countries, and thus allows countries' gross domestic product (GDP) to differ in both level and composition from gross national product (GNP). Since it is generally held that countries' welfare is tied more closely to GNP than to GDP, this simple observation carries considerable importance for governments' trade policy objectives.

This paper evaluates how the conventional understanding of pecuniary cost-shifting between countries must be updated in an environment with internationally integrated equity markets, and how this may translate into an altered role for multilateral trade agreements such as the General Agreement on Tariffs and Trade and its successor institution, the World Trade Organization (GATT/WTO). To this end, the work combines a simple model of endogenous tariff determination under international cross-ownership with the Bagwell and Staiger (1999) (2002) politically augmented terms of trade framework to reexamine the role of negotiated tariff liberalization in an environment with international investment. To capture the policy implications of the broadest possible range of international investment mechanisms in a single framework, the paper restricts attention to the ownership effect 
of investment globalization. ${ }^{1}$ Given the broad view of international investment adopted here, the terms international ownership, cross-border ownership, and international equity holdings, may be taken to be equivalent hereafter.

The model reveals that international ownership dramatically restructures the relationship between national welfare and prices. Whereas traditional (national ownership) models admit a single pecuniary externality through which large countries may extract rents from foreign trading partners, models with international ownership permit three potential costshifting margins. In addition to (potentially) severing the traditionally understood link between a country's terms of trade and its welfare, cross-border ownership introduces two previously unrecognized (potential) cost-shifting margins: the absolute (local relative to world) price level, which can be used to shift rents from local producers (which may be partially foreign owned) to local consumer-constituents, and the local relative price, which may be manipulated to shift rents across sectors - away from those with a relatively high degree of foreign ownership and toward those that are more provincially owned. By formally defining and disentangling these price to welfare mappings, the paper both develops a unified framework for evaluating the trade policy implications of international investment and yields a taxonomy of how the pattern of cross-border ownership influences government objectives and thus the role of negotiated trade agreements.

Incorporating international investment into conventional economic models ranks an increasingly important task as global equity markets become more integrated. The World Bank estimates that between 1990 and 2003, gross private capital flows (the sum of the absolute values of direct, portfolio, and other investment inflows and outflows recorded in the balance of payments) as a percentage of GDP rose from 2.8 to 4.6 in low-income countries, from 6.7 to 13.2 in middle-income countries, and from 11.1 to 26.6 in highincome countries. ${ }^{2}$ This trend towards internationally integrated equity markets has not gone unnoticed. In a series of research projects spanning the trade and international finance

\footnotetext{
${ }^{1}$ This generality comes at a cost, of course, since any economic effects of investment beyond the impact on the pattern of international ownership are necessarily overlooked. For an examination of export-platform international investment as a physical capital flow, see Blanchard (2005a).

${ }^{2}$ World Bank, World Development Indicators 2005, Section 6.1, Table 6.1.
} 
literatures, a number of papers have explored various implications of foreign factor flows or asset market diversification for welfare and trade policy.

The related work within the international trade literature focuses almost exclusively on the welfare and policy implications of international investment (typically modelled as FDI) from the investment-host country perspective, effectively restricting attention to the local or internal - effects of international ownership. Though these papers cluster around several distinct issues: the welfare effects of foreign capital inflows taking tariff policies as fixed, ${ }^{3}$ the potential for "tariff jumping" direct investment, ${ }^{4}$ and the political economy implications of foreign-owned local enterprizes, ${ }^{5}$ they share a common policy implication in the context of this paper. Whether or not explicitly derived, each study implies that a government's optimal tariff (which provides a net transfer from consumers to producers) should decrease with the level of foreign ownership in the host country; intuitively, the local government has less incentive to protect local industry that is owned in part by foreigners.

A pair of innovative articles from the international finance literature examine the policy implications of international equity integration through the lens of asset markets. By focussing on the effect of a country's overseas asset holdings as a part of national ownership, these papers evaluate the external effect of international portfolio diversification. Stockman and Dellas (1986) and Devereux and Lee (1999) explore the welfare and tariff policy implications of internationally integrated asset markets in the presence of risk. ${ }^{6}$ Both papers identify the potential for international ownership to break the link between terms of trade and welfare (as so eloquently stated by Stockman and Dellas), but modelling restrictions in

\footnotetext{
${ }^{3}$ See, for example, Uzawa (1969), Brecher and Diaz-Alejandro (1977), Bhagwati and Brecher (1980) (1981), and Brecher and Findlay (1983).

${ }^{4}$ The foundational paper is Bhagwati, Brecher, Dinopoulos, and Srinivasan (1987); a nice review of subsequent research may be found in Bhagwati, Dinopoulos, and Wong (1992). An interesting recent extension in Konishi, Saggi, and Weber (1999) uses the notion of quid pro quo FDI to explain the use of VERs.

${ }^{5}$ Grossman and Helpman (1996), Olarreaga (1999), Neto (2002), and Blanchard (2002), examine the implications of local foreign ownership on a host government's optimal trade policy using various incarnations of the Grossman and Helpman (1994) 'Protection for Sale' model.

${ }^{6}$ The former explores the effect of exogenous political risk on optimal asset allocation and ex-post national welfare under various (exogenous) tariff policy outcomes, while the latter examines the impact of diversified asset markets on the outcome of a Nash tariff war between two large countries.
} 
each paper prohibit simultaneous consideration of the internal effects of ownership, resulting in some potentially misleading (or at least significantly qualified) policy predictions.

While the key elements of existing work are qualitatively consistent with the model to be presented here, each constitutes only part of the story. In contrast, this paper adopts a unified approach by constructing a generalized model that permits any pattern of international cross-ownership, allows virtually any domestic political economy motives to underly government objectives, and generates policy and welfare predictions for both the investment-host and investment-source countries simultaneously.

In a pedagogical first step, the first part of the paper develops a simple two-country two-good general equilibrium model to demonstrate how the pattern of international ownership enters a national income maximizing government's optimal tariff function. First, assuming that the pattern of international ownership is industry-neutral (equal ownership shares across sectors), the model identifies two distinct channels through which cross border ownership affects governments' optimal tariffs. The first, termed the internal effect, encompasses findings from the related trade literature - that a government's optimal tariff decreases with its recognition of the degree of foreign ownership of local industry. The second, the external effect, generalizes the finding from international finance, and demonstrates that the government has less incentive to manipulate the terms of trade when its constituents hold a stake in the foreign economy.

A brief extension to the basic model then introduces the potential for compositional effects by allowing the inter-sectoral composition of foreign ownership to vary from the industry-neutral benchmark. The thought experiment highlights the potential for sectoral bias in ownership patterns to induce governments to further manipulate prices in favor of those industries with a (relatively) greater degree of national ownership. For instance, foreign ownership bias towards the import-competing sector would strengthen the internal effect in the host country, while weakening the external effect for the foreign (source) country.

This basic version of the model implies that given any equilibrium pattern of production, trade, and prices, both governments' optimal tariffs decline with their recognition of 
the degree of (industry-neutral) international equity integration. Indeed, there may exist sufficiently integrated patterns of international investment that lead both countries to choose internationally efficient tariffs (or even free trade) unilaterally. Interestingly, the efficiency inducing pattern of international cross-ownership falls short of complete portfolio diversification, contrary to an earlier finding by Devereux and Lee (1999). This contradiction highlights the important but potentially surprising role of the internal effect, which in their model is implicitly ruled out by assumptions. Thus, while the generalized model developed in this paper supports Devereux and Lee's qualitative conclusion that opening financial markets may supply a substantial "trade" welfare gain through more liberal tariff regimes, the exercise also emphasizes the finding that perfect portfolio diversification cannot ensure globally efficient tariffs.

Findings from the basic version of the model suggest more generally that the conventional understanding of pecuniary externalities among trading parters must be updated in an environment with internationally integrated equity markets. The model reveals that (i) large countries' ownership interests overseas may mitigate (or even reverse) the conventionally understood link between terms of trade and welfare that would otherwise lead the government to set inefficiently high tariffs (the external effect), (ii) foreign ownership in the local economy introduces an internal cost-shifting externality through which governments can extract rents from foreign investors by manipulating the absolute (local relative to world) price level (the internal effect), and (iii) sectoral bias in the pattern of ownership presents an incentive for governments to further manipulate prices in favor of nationally owned industries (the compositional effect), which may temper or strengthen the internal and external effects depending on the intersectoral distribution of ownership locally and abroad. Although these three effects of international ownership are first identified under the narrow assumption that governments are national income maximizers, it seems evident that observations $(i)-($ iii $)$ should extend to a broad class of political economy models.

Using Bagwell and Staiger's (1999) (2002) politically augmented terms of trade framework, the second half of the paper uses the observations outlined above to formalize several caveats to the prevailing economic theory of the GATT/WTO in an environment with 
cross-border ownership. First, by eroding large countries' external terms of trade costshifting motives, international ownership potentially could release countries from the terms of trade driven prisoners' dilemma that would otherwise necessitate negotiated tariff reductions. This carries the provocative implication that increasingly integrated patterns of international ownership could - at least in theory - substitute for negotiated tariff liberalization in inducing efficient tariff regimes, and thereby supplant completely the current role of the GATT/WTO. Moreover, since foreign ownership introduces an internal cost-shifting opportunity for expropriative policy manipulation that may induce countries to set inefficiently low tariffs, sufficient cross-border ownership could potentially reverse the role of negotiated trade agreements - shifting from an institutional structure designed to facilitate reciprocal tariff liberalization to one that helps countries cooperatively raise their tariffs to globally efficient levels. Yet importantly, the basic principle of reciprocity still serves as an important guide to efficient tariff negotiations regardless of whether unilaterally optimal tariffs are above or below globally efficient levels; countries can achieve Pareto welfare gains by adjusting tariffs in lock-step. It is simply that the formal definition of reciprocal tariff liberalization must be updated in the presence of international ownership - from the existing understanding of reciprocity as symmetric market access concessions to an adjustment process that balances countries' external and internal ownership positions together with the traditionally defined terms of trade.

The paper proceeds as follows. The next section develops a model to identify the internal, external, and compositional effects of international ownership on national income maximizing governments' optimal tariffs and argues that there may exist patterns of international investment that are sufficiently integrated to induce countries to choose internationally efficient tariffs (or even free trade) unilaterally. Section 3 then explores the implications of international portfolio integration for the GATT/WTO by formalizing how cross-ownership redefines pecuniary externalities among large countries, and how these changes may be formalized in the Bagwell-Staiger politically augmented terms of trade framework. Section 4 concludes. 


\section{Cost-shifting and International Investment}

This section develops a simple two-country two-good general equilibrium model with exogenous international cross-ownership. Governments are assumed to be apolitical national income maximizers; this simplification offers a clear characterization of the optimal tariff as the sum of the standard large country terms of trade cost-shifting externality, an internal effect (how foreign ownership of local production influences tariff choice), and an external effect (how domestic ownership of overseas production affects the optimal tariff decision). Later, Section 3 argues that the results from this section extend qualitatively to a broad class of (potentially politically motivated) government objectives.

\subsection{The Model}

Two large countries, Home and Foreign, may produce and trade 2 goods, $x$ and $y$, with constant returns to scale technologies and under the assumption of increasing opportunity costs. Preferences are assumed to be identical and homothetic (the assumptions on preferences are necessary only for the discussion of reciprocity in Appendix 5.4).

International ownership is modelled as non-resident claims on domestic production, which is paid the local output price. ${ }^{7}$ Defining international ownership as a claim on output rather than on the return to a given factor of production simplifies analysis considerably, since the rate of return to foreign owners is then homogenous of degree one in the local price. ${ }^{8}$ The pattern of international ownership is taken to be exogenous so that the model can remain agnostic regarding the mechanism through which such bilateral cross-holdings arise - whether via international capital flows, acquisition of domestic firms by foreigners,

\footnotetext{
${ }^{7}$ The assumption that the return to overseas investment depends on the foreign local price is consistent with Bhagwati and Brecher (1980) and Neary (1995) for example, and reflects that trade taxes are levied on goods based on location of production rather than ownership.

${ }^{8}$ If instead international ownership was modelled as non-resident claims on the return to one of several factors of production (such as capital), the magnitude (but not the direction) of a change in the local price on foreign remittances would depend on the proportion of the price change absorbed by other factors of production (such as labor). In effect, modelling foreign ownership as a claim on output may be understood as a reduced form of modelling foreign factor ownership.
} 
international portfolio diversification, or some other means. ${ }^{9}$

Denote the percentage of Home production of good $i \in\{x, y\}$ held in Foreign claims by $\phi_{i}$. Similarly, use $\phi_{i}^{*}$ to represent the percentage of claims on Foreign located industry $i$ production held by Home residents. Attention is restricted to industry neutral patterns of international ownership, for which $\phi_{x}=\phi_{y} \equiv \phi$ and $\phi_{x}^{*}=\phi_{y}^{*} \equiv \phi^{*}$. (This assumption is relaxed temporarily later in the section to explore the compositional effects of industry bias in ownership patterns.) So defined, $\phi$ and $\phi^{*}$ measure international equity integration; the higher is $\phi\left(\phi^{*}\right)$, the greater the proportion of Home (Foreign) production owned by non-residents. From the perspective of the Home government, $\phi$ designates internal foreign ownership, and $\phi^{*}$ external ownership of production overseas.

Governments are restricted to a single trade policy instrument in the form of import tariffs. In standard models without international ownership this is simply a privilege afforded by Lerner symmetry. Here, however, this constitutes an explicit assumption since import tariffs and export taxes may have asymmetric effects on the real economy in the presence of cross-border asset holdings, as demonstrated in Blanchard (2005b). ${ }^{10}$ Since this paper's focus is to explore the implications of international ownership for the GATT/WTO - an institution designed explicitly for the cooperative reduction of tariffs - the restricted instrument set seems most appropriate.

Let good $y$ act as numeraire such that $p \equiv \frac{p_{x}}{p_{y}}$ represents Home's local price ratio. Using an asterisk $\left(^{*}\right)$ to denote foreign country variables, the foreign local price ratio is $p^{*} \equiv \frac{p_{x}^{*}}{p_{y}^{*}}$. Assuming that Home's natural import good is $x$, the world ratio of offshore export prices is $p^{w} \equiv \frac{p_{x}^{*}}{p_{y}}$, and the Home (Foreign) terms of trade is $\frac{1}{p^{w}}\left(p^{w}\right)$. Using $t\left(t^{*}\right)$ to represent the Home (Foreign) ad valorem import tariff, each country's domestic relative price may

\footnotetext{
${ }^{9}$ Though taking international ownership as exogenous constitutes rather a heroic simplification of the model, it is well precedented. For example, Bhagwati and Brecher (1981) assume fixed supplies of foreign inputs, but argue convincingly that their model nonetheless provides a meaningful caution to nationally oriented policy makers not to automatically adopt the standard welfare conclusions about trade policies in an environment with international ownership.

${ }^{10}$ Tariffs increase the local absolute (home relative to world) price level, which shifts rents from consumers to producers, whereas export taxes cause the absolute price level to fall, benefitting consumers at the expense of producers.
} 
then be written a function of the world price and the local tariff, $p=\tau p^{w} \equiv p\left(\tau, p^{w}\right)$ and $p^{*}=\frac{p^{w}}{\tau^{*}} \equiv p^{*}\left(\tau^{*}, p^{w}\right)$ where $\tau \equiv(1+t)$ and $\tau^{*} \equiv\left(1+t^{*}\right)$.

Production occurs at the point on each country's production possibilities frontier where the marginal rate of technical substitution equals the domestic price ratio; it follows that Home (Foreign) production of each good $i$ may be written as a function of the local relative price only, $q_{i}(p)\left(q_{i}^{*}\left(p^{*}\right)\right)$ for $i \in\{x, y\}$. Assuming Gorman form preferences ensures that aggregate Home (Foreign) demand for each good depends on only local prices and national income, $I\left(I^{*}\right)$, so that $d_{i} \equiv d_{i}(p, I)$ and $d_{i}^{*} \equiv d_{i}^{*}\left(p^{*}, I^{*}\right)$ for $i \in\{x, y\}$.

Expressed in units of the local export good measured at the world price, the Home and Foreign income levels $I\left(p, p^{w}, p^{*}\right)$ and $I^{*}\left(p, p^{w}, p^{*}\right)$ are determined implicitly by the respective equations: ${ }^{11}$

$$
\begin{aligned}
I=(1-\phi)\left[p q_{x}(p)+q_{y}(p)\right] & +\phi^{*} \tau^{*}\left[p^{*} q_{x}^{*}\left(p^{*}\right)+q_{y}^{*}\left(p^{*}\right)\right] \\
& +\left(p-p^{w}\right)\left[d_{x}(p, I)-q_{x}(p)\right]
\end{aligned}
$$

and,

$$
\begin{aligned}
I^{*}=\left(1-\phi^{*}\right)\left[q_{x}^{*}\left(p^{*}\right)+\frac{1}{p^{*}} q_{y}^{*}\left(p^{*}\right)\right] & +\phi \tau\left[q_{x}(p)+\frac{1}{p} q_{y}(p)\right] \\
& +\left(\frac{1}{p^{*}}-\frac{1}{p^{w}}\right)\left[d_{y}^{*}\left(p^{*}, I^{*}\right)-q_{y}^{*}\left(p^{*}\right)\right] .
\end{aligned}
$$

Notice that these income expressions represent gross national product (GNP) rather than gross domestic product (GDP) since they incorporate remittances from abroad and payments to foreigners.

\footnotetext{
${ }^{11}$ The real income expressions in (2.1) and (2.2) are derived by dividing Home and Foreign money income, $I^{m}$ and $I^{m *}$, by $p_{y}$ and $p_{x}^{*}$ respectively, where:

$$
\begin{aligned}
I^{m} & =(1-\phi)\left[p_{x} q_{x}(p)+p_{y} q_{y}(p)\right]+\phi^{*}\left[p_{x}^{*} q_{x}^{*}\left(p^{*}\right)+p_{y}^{*} q_{y}^{*}\left(p^{*}\right)\right]+\left(p_{x}-p_{x}^{*}\right)\left[d_{x}(p, I)-q_{x}(p)\right], \text { and } \\
I^{m *} & =\left(1-\phi^{*}\right)\left[p_{x}^{*} q_{x}^{*}\left(p^{*}\right)+p_{y}^{*} q_{y}^{*}\left(p^{*}\right)\right]+\phi\left[p_{x} q_{x}(p)+p_{y} q_{y}(p)\right]+\left(p_{y}^{*}-p_{y}\right)\left[d_{y}^{*}\left(p^{*}, I^{*}\right)-q_{y}^{*}\left(p^{*}\right)\right] .
\end{aligned}
$$

Note that under the arbitrage conditions, $\tau^{*}=\frac{p^{w}}{p^{*}}$ and $\tau=\frac{p}{p^{w}}$ so that (2.1) and (2.2) are indeed functions of $p, p^{w}$, and $p^{*}$.
} 
Both countries are assumed to satisfy their respective balanced budget conditions: ${ }^{12}$

$$
\begin{aligned}
p^{w} M_{x} & =E_{y}+\Phi, \text { and } \\
M_{y}^{*} & =p^{w} E_{x}^{*}-\Phi,
\end{aligned}
$$

where $\Phi \equiv \phi^{*} \tau^{*}\left[p^{*} q_{x}^{*}+q_{y}^{*}\right]-\phi\left[p q_{x}+q_{y}\right]$ represents net remittances paid by Foreign to Home measured in units of good $y$ at the world price; ${ }^{13} M_{x}(p, I) \equiv d_{x}(p, I)-q_{x}(p)$ denotes Home's imports of good $x ; E_{y}(p, I) \equiv q_{y}(p)-d_{y}(p, I)$ is Home's exports of $y ; M_{y}^{*}\left(p^{*}, I^{*}\right) \equiv$ $d_{y}^{*}\left(p^{*}, I^{*}\right)-q_{y}^{*}\left(p^{*}\right)$ is Foreign imports of $y$; and $E_{x}^{*}\left(p^{*}, I^{*}\right) \equiv q_{x}^{*}\left(p^{*}\right)-d_{x}^{*}\left(p^{*}, I^{*}\right)$ is Foreign exports of $x$.

The equilibrium world price, $\tilde{p}^{w} \equiv \tilde{p}^{w}\left(\tau, \tau^{*}\right)$, is determined by the goods market clearing condition:

$$
E_{x}^{*}\left(p\left(\tau, \tilde{p}^{w}\right), \tilde{p}^{w}, p^{*}\left(\tau^{*}, \tilde{p}^{w}\right)\right)=M_{x}\left(p\left(\tau, \tilde{p}^{w}\right), \tilde{p}^{w}, p^{*}\left(\tau^{*}, \tilde{p}^{w}\right)\right) .
$$

By Walras' law, the market for $y$ must also clear if the preceding holds and countries abide by their budget constraints. Finally, ruling out the Metzler and Lerner paradoxes ensures that:

$$
\begin{aligned}
\frac{d p\left(\tau, \tilde{p}^{w}\left(\tau, \tau^{*}\right)\right)}{d \tau} & >0>\frac{\partial \tilde{p}^{w}\left(\tau, \tau^{*}\right)}{\partial \tau}, \quad \text { and } \\
\frac{d p^{*}\left(\tau^{*}, \tilde{p}^{w}\left(\tau, \tau^{*}\right)\right)}{d \tau^{*}} & <0<\frac{\partial \tilde{p}^{w}\left(\tau, \tau^{*}\right)}{\partial \tau^{*}} .
\end{aligned}
$$

\footnotetext{
${ }^{12}$ The balanced budget conditions in (2.3) and (2.4) are found by setting the value of each country's consumption at local prices equal to its money income (i.e. $p_{x} d_{x}+p_{y} d_{y}=I^{m}$ for Home and $p_{x}^{*} d_{x}+p_{y}^{*} d_{y}=I^{m *}$ for Foreign), rearranging, and dividing by $p_{y}$.

${ }^{13}$ By allowing permanent trade imbalances this model differs from most, since virtually all international trade models impose balanced trade $(\Phi \equiv 0)$. Yet even the assumption of balanced trade constitutes an explicit (and often inappropriate) restriction in the presence of international investment; when foreign remittances depend on local prices (as assumed here), the value of $\Phi$ depends on $\tau$ and $\tau^{*}$. Indeed, the assumption of balanced trade is doubly restrictive when trade policy is endogenous, since national income maximizing governments have an incentive to manipulate domestic prices to engineer trade deficits at the expense of foreign investors, as first shown by Blanchard (2005b).
} 


\subsection{Optimal Tariffs and the Pattern of International Ownership}

Home's Optimal Tariff. The Home government chooses its tariff to maximize the indirect utility of a representative consumer subject to the market clearing condition (2.5), where indirect utility, $v(p, I)$, is a function of the domestic price at which goods may be purchased and income: ${ }^{14}$

$$
\begin{array}{r}
\tau^{o}=\arg \max _{\tau} v\left(p\left(\tau, p^{w}\right), I\left(p\left(\tau, p^{w}\right), p^{w}, p^{*}\left(\tau^{*}, p^{w}\right)\right)\right), \\
\text { s.t. } \quad p^{w}=\tilde{p}^{w}\left(\tau, \tau^{*}\right) .
\end{array}
$$

Forming the Lagrangian restates the government's problem:

$$
\max _{\tau, p^{w}} \quad L=v\left(p\left(\tau, p^{w}\right), I\left(p\left(\tau, p^{w}\right), p^{w}, p^{*}\left(\tau^{*}, p^{w}\right)\right)\right)-\gamma\left(p^{w}-\tilde{p}^{w}\left(\tau, \tau^{*}\right)\right)
$$

where $\gamma>0$ is the Lagrangian multiplier. After straightforward algebraic manipulation, the first order condition may be written as:

$$
V_{\tau}=v_{I}[\underbrace{t \tilde{p}^{w} \frac{d E_{x}^{*}}{d \tau}-E_{x}^{*} \frac{\partial \tilde{p}^{w}}{\partial \tau}}_{\text {standard TOT motive }}+\underbrace{\phi^{*} q_{x}^{*} \frac{\partial \tilde{p}^{w}}{\partial \tau}}_{\text {external effect }}+\underbrace{-\phi q_{x} \frac{d p}{d \tau}}_{\text {internal effect }}]=0 .
$$

The expression in (2.10) reveals that there are three competing influences on the government's optimal tariff decision: the standard large country terms of trade motive to set a positive tariff, the effect of Home's external ownership of Foreign production, and the influence of internal Foreign ownership of Home's local production. Notice that the external effect is driven by Home's ownership in the Foreign export sector, whereas the internal effect depends on the degree of Foreign ownership in Home's import sector. This is intuitive. To the extent that Home constituents hold equity interests the Foreign export sector, their government will be less inclined to levy an import tariff at their expense; the greater

\footnotetext{
${ }^{14}$ Care must be taken to evaluate the derivative of Home's income expression, since fixing any two of the five variables $p, \tilde{p}^{w}, p^{*}, \tau$, and $\tau^{*}$ determines uniquely the equilibrium values of the remaining three. For instance, since $p^{*}$ is determined uniquely by $p$ and $\tilde{p}^{w}$, the effect of a marginal change in $p^{*}$ on income holding $p$ and $p^{w}$ fixed $\frac{\partial I^{*}\left(p, p^{w}, p^{*}\right)}{\partial p^{*}}$ can be evaluated only by allowing $p^{w}$ to differ from its market clearing value, $\tilde{p}^{w}$. See Section 3 for a more detailed discussion of the equilibrium relationships among prices and tariffs.
} 
the proportion of the foreign export sector that Home recognizes as its own, $\phi^{*}$, the lower its optimal tariff. Similarly, since a tariff acts as a subsidy to the domestic import sector at the expense of local consumers, the Home government will have less motive to provide protection to the import competing industry, the greater is $\phi$.

Solving the first order condition in (2.10) yields the implicit form of Home's optimal tariff:

$$
\tau^{o}=1+\frac{1}{\hat{\epsilon}_{x}^{*}}\left(1-\frac{\phi^{*} q_{x}^{*}}{E_{x}^{*}}+\frac{\phi q_{x}}{M_{x} \lambda}\right)
$$

where $\lambda \equiv \frac{\frac{\partial p^{w}}{\partial \tau}}{\frac{d p}{d \tau}}$, which is $<0$ by $(2.6)$, and $\hat{\epsilon}_{x}^{*} \equiv \epsilon_{x}^{*}+\frac{\partial E_{x}^{*}\left(p^{*}, I^{*}\right)}{\partial I^{*}} \frac{\partial I^{*}\left(p, p^{w}, p^{*}\right)}{\partial p} \frac{p^{w}}{E_{x}^{*}} \frac{1}{\lambda}$, where $\epsilon_{x}^{*} \equiv \frac{d E_{x}^{*}}{d p^{w}} \frac{p^{w}}{E_{x}^{*}}$ is Foreign export supply elasticity. Note that in the absence of international ownership, (2.11) reduces to the familiar Johnson (1951-52) terms of trade cost-shifting tariff, $\tau=1+\frac{1}{\epsilon_{x}^{*}} .{ }^{15}$ XThis optimal tariff expression reinforces the earlier intuition, since it is again clear that the internal and external effects of international ownership work in tandem to counter Home's 'standard' large-country terms of trade motivation for manipulating the world price. And indeed, as long as the direct effect of increasing the degree of crossownership (how $\phi$ and $\phi^{*}$ enter (2.11) explicitly) outweighs any possible indirect effects of changing the pattern of international ownership ${ }^{16}$ (which are generally ambiguous in sign), an increase in industry-neutral international integration will cause Home's optimal tariff to fall.

At the same time, it is clear that the tariff liberalizing potential of international ownership must in general depend crucially on the trade orientation of those sectors with foreign stake holders. Temporarily removing the the restriction of industry neutrality yields the modified optimal tariff expression:

$$
\tau^{o}=1+\frac{1}{\hat{\epsilon}_{x}^{*}}(1-\frac{\phi_{x}^{*} q_{x}^{*}}{E_{x}^{*}}+\frac{\phi_{x} q_{x}}{M_{x} \lambda}+\underbrace{\frac{\left(\phi_{x}^{*}-\phi_{y}^{*}\right) p^{*} q_{x}^{\prime *}\left(p^{*}\right)}{E_{x}^{*}}+\frac{\left(\phi_{x}-\phi_{y}\right) p q_{x}^{\prime}(p)}{M_{x} \lambda}}_{\text {compositional effects }}) .
$$

\footnotetext{
${ }^{15}$ From the implicit definition of Foreign income in $(2.1), \frac{\partial I^{*}\left(p, p^{w}, p^{*}\right)}{\partial p}=\frac{\phi q_{x}}{1+t^{*} p^{*} \frac{d_{\tilde{x}}\left(p^{*}, I^{*}\right)}{\partial I^{*}}}$. Thus, $\phi=0 \rightarrow$ $\hat{\epsilon}_{x}^{*}=\epsilon_{x}^{*}$.

${ }^{16}$ Changing $\phi$ and $\phi^{*}$ may affect equilibrium trade volume and foreign export supply elasticity via income effects.
} 
The compositional effects identified above describe the potential for industry-bias in the pattern of international ownership to further influence Home's optimal tariff. Export-sector bias in Home's overseas ownership $\left(\phi_{x}^{*}>\phi_{y}^{*}\right)$, would further reduce Home's incentive to manipulate the terms of trade, while ownership bias towards the foreign import-competing sector $\left(\phi_{y}^{*}>\phi_{x}^{*}\right)$ would counter the 'direct' influence of the external effect. Similarly, while a Foreign ownership bias towards Home's import-competing sector $\left(\phi_{x}>\phi_{y}\right)$ would strengthen the internal effect on Home's tariff, disproportionate Foreign ownership in Home's export sector would enter the Home optimal tariff function with the opposite sign.

Intuitively, any change in local relative prices, which causes the pattern of domestic output to shift along a country's production possibilities frontier, redistributes returns between industries. To the extent that there exists industry-bias in the pattern of ownership, this implies a net redistribution between domestic and foreign producers. Thus, as demonstrated by (2.12), any industry bias in the pattern of ownership will either moderate or further strengthen the 'direct' internal and external effects depending on the direction of bias. In the context of this model, the internal and external effects of international ownership will swamp any potential compositional effects as long as the pattern of ownership is not too heavily biased towards sector $y$. To simplify exposition and notation, the remainder of the paper now re-invokes the assumption of industry-neutral ownership.

The Foreign Optimal Tariff. The Foreign economy mirrors that of Home, where $y$ is the Foreign import sector and the Home country's export sector. The full characterization of the Foreign government's optimization problem is reserved for the appendix, since it exactly parallels that for Home. Jumping directly to the result, it is clear that the implicit expression for the Foreign optimal tariff is analogous to (2.11):

$$
\tau^{* o}=1+\frac{1}{\hat{\epsilon}_{y}}\left(1-\frac{\phi q_{y}}{E_{y}}+\frac{\phi^{*} q_{y}^{*}}{M_{y}^{*}} \frac{1}{\lambda^{*}}\right)
$$

where $\lambda^{*} \equiv \frac{\frac{\partial \frac{1}{p^{w}}}{\partial \tau^{*}}}{\frac{d p^{*}}{d \tau^{*}}}<0$ by $(2.7)$ and $\hat{\epsilon}_{y} \equiv \epsilon_{y}+\frac{\partial E_{y}(p, I)}{\partial I} \frac{\partial I\left(p, p^{w}, p^{*}\right)}{\partial p^{*}} \frac{1}{p^{w}} \frac{1}{E_{y}} \frac{1}{\lambda^{*}}$, where $\epsilon_{y} \equiv \frac{d E_{y}}{d \frac{1}{p^{w}}} \frac{1}{p^{w}} \frac{1}{E_{y}}$ is Home's elasticity of export supply. Again, in the absence of cross ownership this reduces to the standard Johnson cost-shifting tariff. 
Just as in the Home country case, both internal $\left(\phi^{*}\right)$ and external $(\phi)$ cross-holdings enter the Foreign optimal tariff expression negatively. All else equal, the Foreign government's incentive to impose a tariff decreases both with the fraction of the local import-competing sector owned by Home constituents, $\phi^{*} q_{y}^{*}$, and with the share of Home's export sector owned by Foreigners, $\phi q_{y}$. Thus, given any equilibrium pattern of production, trade volume, and Foreign export supply elasticity, the Foreign country's optimal tariff is lower, the greater the degree of international integration.

The tariff liberalizing potential of international ownership carries a number of policy implications. For instance, the external effect of overseas ownership introduces the possibility that by welcoming investment from a trading partner, a country may be able to induce the investing country to reduce its import tariffs unilaterally. This is a previously unidentified benefit of attracting overseas investors; in addition to conventionally cited gains such as capital growth, employment, or technology transfer, foreign investment in the local export sector can improve existing domestic exporters' market access in the investment-source country. ${ }^{17}$

At the same time, the internal effect of international investment admits an intriguing reinterpretation of Bhagwati, Brecher, Dinopoulos, and Srinivasan (1987), which argues that foreign export-oriented firms may establish import-competing subsidiaries in a target country in an effort to jump an existing tariff or to defuse a protectionist threat. The authors posit that such tariff-jumping foreign investment may reduce the host country's tariff due to "political goodwill" on the part of local politicians who appreciate the job creation that follows from subsidiary investment. This model justifies their assumption that an increase in local foreign investment causes the host-country tariff to decline, but it is not political goodwill that reduces the host-country tariff. Quite the opposite, the investment host government has an incentive to decrease its tariff to extract rents from foreign investors in the local import competing sector. More generally, if foreign investors earn excess returns, there exists an internal cost-shifting opportunity whereby the local

\footnotetext{
${ }^{17}$ Blanchard (2005a) explores this possibility further by asking whether potential investment-host countries should in fact subsidize foreign direct investment to gain such preferential tariff treatment.
} 
government can manipulate local prices through tariff reductions to extract rents from foreign interests in the local import sector.

\subsection{Efficiency Inducing Patterns of Ownership}

Perhaps the model's most provocative suggestion is that by leading governments to liberalize their tariffs unilaterally, international integration may be able to substitute partially (or in some instances completely) for negotiated tariff reductions. Just as in any standard (noFDI) model with national income maximizing governments, the set of efficient tariffs is characterized by the Mayer (1981) condition:

$$
\tau=\frac{1}{\tau^{*}}
$$

(Proof in appendix 5.2) Substituting the optimal tariff expressions (2.11) and (2.13) into the efficiency condition (2.14) defines implicitly a set of $\left(\phi, \phi^{*}\right)$ pairs for which the outcome of a Nash tariff war between Home and Foreign would be internationally efficient. It is not surprising given the model's generality that the resulting efficiency condition yields little economic insight. Analytically simpler than a general characterization of the conditions for efficiency, the free trade case (sufficient but not necessary) yields better insight with fewer complications.

Setting Home's optimal tariff expression in (2.11) equal to one and rearranging defines implicitly the set of $\left(\phi, \phi^{*}\right)$ pairs that would induce Home to set a zero tariff:

$$
\phi^{*}=\frac{E_{x}^{*}}{q_{x}^{*}}\left(1+\frac{\phi q_{x}}{M_{x}} \frac{1}{\lambda}\right)
$$

Likewise, Foreign's optimal unilateral tariff policy is free trade when:

$$
\phi=\frac{E_{y}}{q_{y}}\left(1+\frac{\phi^{*} q_{y}^{*}}{M_{y}^{*}} \frac{1}{\lambda^{*}}\right) .
$$

Together, (2.15) and (2.16) define a free trade inducing pattern of international ownership $\left(\phi^{f t}, \phi^{* f t}\right)$ that counters exactly the Home and Foreign countries' standard large country motive to manipulate the world price. Of course, there is no reason to expect existence or uniqueness of such a free trade inducing pattern of ownership in general due to the implicit nature of the problem. 
Notice in both countries that in the absence of internal ownership each government's optimal tariff is zero when the volume of its overseas owned production equals its import volume (e.g. in Home, when $\phi=0, \tau^{0}=1$ when $q_{x}^{*} \phi^{*}=E_{x}^{*}$ ). This is intuitive; when a country owns overseas exactly as much as it imports (and owns all of its local production), it is neither a net consumer nor a net producer of that good, and thus has no incentive to manipulate the world price. Or in other words, perfect portfolio diversification breaks the link between a country's terms of trade and its welfare, as shown first by Stockman and Dellas (1986). But importantly, if there also is internal ownership so that foreign investors hold some claim to local production, that same level of external ownership will induce a negative tariff, since the internal effect excites the government's expropriative inclinations. If tariffs are the government's only policy instrument as assumed here, the result is an import subsidy. Were more direct means by which to capture foreign investors rents available - for instance through a tax on foreign remittances - the government's first best policy instead would be a direct tax on remittances, removing the internal cost-shifting effect from the optimal tariff decision. ${ }^{18}$

Interestingly, this implies that any efficiency inducing pattern of industry-neutral ownership would necessarily fall short of complete portfolio diversification. At first glance, this seems to contradict a finding by Devereux and Lee (1999), who found that free trade is a Nash equilibrium of a tariff war when international financial markets are fully diversified. ${ }^{19}$ The contradiction derives from a critical difference in model assumptions. Devereux and Lee's framework, which develops a parameterized two country of optimal financial risk sharing to show that if tariffs are determined optimally by national income maximizing governments, implicity rules out internal cost shifting by assuming that return to overseas investment is unaffected by local tariffs; this leaves only terms of trade motives to drive trade

\footnotetext{
${ }^{18}$ See Blanchard (2005b) for formal treatment of tariffs as a second best instrument for expropriating foreign investors' returns.

${ }^{19}$ Under complete diversification and starting from free trade, each country will consume as much as it owns in each industry (recall that preferences are identical and homothetic). Thus, starting from free trade when Home is completely diversified, $\phi^{*} q_{x}^{*}=E_{x}^{*}+\phi q_{x}$. But comparing this expression to the free trade requirement in (2.15) reveals that Home's optimal tariff will be zero when it is completely diversified if and only if $\phi=0$. But if $\phi=0$ and $\phi^{*}>0$ the foreign optimal tariff will be negative by (2.13).
} 
policy. ${ }^{20}$ Absent the internal effects of international ownership, this model thus presents a generalized version of theirs. More generally, the results outlined here qualitatively support their conclusion that when tariffs are endogenous, opening financial markets can supply a secondary trade welfare gain in addition to the direct benefit of risk-sharing.

Building on the finding that international equity integration can serve as a tariff liberalizing force in a model with apolitical national income maximizing governments, the next section argues that this observation extends to a broad class of government objectives, and discusses the implications for the prevailing economic interpretation of the GATT/WTO in an environment with international ownership.

\section{Achieving Efficiency: Negotiation vs. Integration}

Multilateral trade forums are understood increasingly to be a solution to a terms of trade driven prisoners' dilemma among large economies $;{ }^{21}$ sufficiently large countries can engineer their local trade policies to manipulate world prices in their favor, but when every country follows a unilaterally optimal policy of using tariffs to achieve terms of trade gains, their competing efforts to influence the world price will cancel one another (given sufficient symmetry) leaving only the local distortionary effects of protectionism. Although every country could be made better off under universally lower tariffs, none will liberalize unilaterally for fear of the consequent damage to its terms of trade.

Bagwell and Staiger (2002) construct a theoretical framework to formalize this insight, and in so doing articulate a comprehensive economic interpretation the role of the

\footnotetext{
${ }^{20}$ Specifically, Devereux and Lee develop a two-period model in which two symmetric countries with Cobb-Douglas preferences trade state contingent contracts in the first period for second period delivery and consumption. There is no production and second period endowments follow a stochastic process that is ex-ante symmetric across countries (so that countries' ex-ante budget constraints are identical). Critically, the authors assume that second period deliveries exempt from stage two tariffs, which eliminates the internal cost-shifting motive identified here.

${ }^{21}$ Other theories of negotiated tariff liberalization, for instance as commitment devices for time-inconsistent governments (i.e. Maggi and Rodriguez-Clare (1998) and Ornelas (2002)), are set aside in this paper. Whether international investment can substitute for multilateral agreements as a time consistent commitment mechanism seems an interesting topic for future work.
} 
GATT/WTO and its rules. A key innovation of their work is the observation that virtually any government policy objectives may be characterized as function of the local price and the equilibrium terms of trade. Thus, they show that in a two country model, government objectives may be written:

$$
\begin{aligned}
W & \equiv W\left(p, \tilde{p}^{w}\right), \\
W^{*} & \equiv W^{*}\left(p^{*}, \tilde{p}^{w}\right) .
\end{aligned}
$$

Bagwell and Staiger argue that representing government preferences in this way admits a ready interpretation of the GATT/WTO while maintaining great latitude governments' redistributional concerns or ideological preferences. ${ }^{22}$ They impose a single restriction on the objective functions: that holding the local price fixed, government welfare increases with the country's terms of trade (i.e. $W_{\tilde{p}^{w}}<0$ and $W_{\tilde{p}^{w}}^{*}>0$ where Home exports the numeraire good), so that regardless of domestic political objectives, any country sufficiently large to manipulate the world price has an incentive to do so.

Noting that the Home and Foreign governments' unilaterally optimal tariffs, $\tau^{o}$ and $\tau^{* o}$, satisfy the respective first order conditions:

$$
\begin{aligned}
\frac{d W}{d \tau} & =W_{p}+\lambda W_{\tilde{p}^{w}}=0 \\
\frac{d W^{*}}{d \tau^{*}} & =W_{p^{*}}^{*}+\lambda^{*} W_{\tilde{p}^{w}}^{*}=0 .
\end{aligned}
$$

where $\lambda \equiv \frac{\frac{\partial p^{w}}{\partial \tau}}{\frac{d p}{d \tau}}<0$ and $\lambda^{*} \equiv \frac{\frac{\partial p^{w}}{\partial \tau^{*}}}{\frac{d p^{*}}{d \tau^{*}}}<0$ by $(2.6)-(2.7)$, Since $\lambda<0$ it must be true that at the unilaterally optimal tariff $W_{p}<0$. That is, the Home government's unilaterally optimal tariff is higher than it would be in the absence of terms of trade concerns. (Given the symmetry of the problem, the same is true for the foreign counterpart: the Foreign unilaterally optimal tariff is higher than it would be in the absence of terms of trade concerns.) From these first order conditions, Bagwell and Staiger make three observations concerning the

\footnotetext{
${ }^{22}$ Since it imposes no restrictions on government preferences over the local price (holding the terms of trade fixed), this politically augmented terms of trade framework admits a broad class of political economy models in addition to the traditional case of national income maximizing governments. See Bagwell and Staiger (1999) or (2002) for further discussion.
} 
efficiency of countries' unilaterally optimal (Nash) tariffs. ${ }^{23}$ They prove that (i) Nash equilibrium tariffs are inefficient, (ii) Pareto improving trade negotiations must imply mutual tariff liberalization (Nash equilibrium tariffs are higher than is efficient), and (iii) the terms of trade externality is the only source of international inefficiency (politically optimal tariffs are efficient $\left.{ }^{24}\right)$.

Together, $(i)$ and $(i i)$ imply that value of a trade agreement lies in governments' ability to achieve mutual welfare gains via reciprocal trade liberalization. That is, holding the world price fixed, each country can improve its welfare from at least a marginal reduction in its tariff. The third observation implies that eliminating terms of trade externalities among large countries (either by making big countries "act small" by simply ignoring the outside effects of their tariff decisions or via synchronized tariff reductions in accordance with the GATT/WTO principle of reciprocity) is sufficient to ensure efficiency.

Yet these observations depend crucially on the nature of pecuniary externalities, while the findings from the first part of this paper suggest that the pattern of international ownership can restructure dramatically the economic relationships among countries. International equity integration may mitigate (or even reverse) terms of trade externalities, while simultaneously introducing an internal cost-shifting externality through which governments can extract rents from foreign investors by manipulating domestic prices. The next paragraphs identify the internal and external effects of international ownership within the BagwellStaiger framework to formalize how international investment recharacterizes potential price externalities between trading partners, demonstrating the applicability of the observations from Section 2 to a broad class of political economy models.

Returning to the bilateral model from part one of the paper, relax only the assumption that governments are national income maximizers; leave everything else unchanged. It is pedagogically useful to define the government objective functions in two stages. Though somewhat unorthodox, this two-step technique introduces an intermediate welfare function that proves notationally useful in disentangling the welfare effects of price changes. In step one, define government welfare as a function of tariffs and the world price, absent the

\footnotetext{
${ }^{23}$ See Bagwell and Staiger (2002) pp. 23-25, or Propositions 1-3 in Bagwell and Staiger (1999).

${ }^{24}$ Politically optimal tariffs $\tau^{P O}$ and $\tau^{* P O}$ are defined implicitly by $W_{p}=0$ and $W_{p^{*}}^{*}=0$ respectively.
} 
market clearing condition. Then in step two, impose market clearing, $p^{w}=\tilde{p}^{w}\left(\tau, \tau^{*}\right)$, to define the "equilibrium" government objective functions that parallel Bagwell and Staiger's (3.1) - (3.2). ${ }^{25}$ That is, first let

$$
w\left(p, p^{w}, p^{*}\right) \equiv w\left(p\left(\tau, p^{w}\right), p^{w}, p^{*}\left(\tau^{*}, p^{w}\right)\right)
$$

and

$$
w^{*}\left(p, p^{w}, p^{*}\right) \equiv w^{*}\left(p^{*}\left(\tau^{*}, p^{w}\right), p^{w}, p\left(\tau, p^{w}\right)\right)
$$

represent Home and Foreign welfare respectively, where $p^{w}$ is unrestricted, but arbitrage conditions maintain that $p=\tau p^{w}$ and $\tau^{*} p^{*}=p^{w}$. (Note that if Home and Foreign were small countries, the preceding expressions would also represent the governments' (equilibrium) objective functions for any given (exogenous) world price.) Since Home and Foreign are large countries, the equilibrium welfare functions - the governments' objective functions must incorporate that each government's tariff choice affects the world price. Thus, the equilibrium government objective functions are given by:

$$
\left.W\left(p, \tilde{p}^{w}\right) \equiv w\left(p, p^{w}, p^{*}\right)\right|_{p^{w}=\tilde{p}^{w}\left(\tau, \tau^{*}\right)}
$$

and

$$
\left.W^{*}\left(p^{*}, \tilde{p}^{w}\right) \equiv w^{*}\left(p^{*}, p^{w}, p\right)\right|_{p^{w}=\tilde{p}^{w}\left(\tau, \tau^{*}\right)} .
$$

Notice that imposing the market clearing constraint reduces the number of arguments in the objective functions in (3.7)-(3.8). This is because the market clearing and balanced budget conditions in (2.3)-(2.5), together with the arbitrage conditions, imply that fixing any two of the five variables $p, \tilde{p}^{w}, p^{*}, \tau$, and $\tau^{*}$ determines the equilibrium values of the remaining three when both countries are large. ${ }^{26}$ For example, choosing any $\left(\tau, \tau^{*}\right)$ pair determines equilibrium prices according to $\tilde{p}^{w}\left(\tau, \tau^{*}\right), p\left(\tau, \tilde{p}^{w}\left(\tau, \tau^{*}\right)\right)$, and $p^{*}\left(\tau^{*}, \tilde{p}^{w}\left(\tau, \tau^{*}\right)\right)$.

\footnotetext{
${ }^{25}$ Note that this is the same technique used in Section 2.2, in which the government maximizes indirect utility $v\left(p\left(\tau, p^{w}\right), I\left(p\left(\tau, p^{w}\right), p^{w}, p^{*}\left(\tau^{*}, p^{w}\right)\right)\right)$ subject to the constraint the market clearing constraint, $p^{w}=$ $\tilde{p}^{w}\left(\tau, \tau^{*}\right)$.

${ }^{26} \mathrm{~A}$ possible exception is that a $\left(p, p^{*}\right)$ pair may not determine the other variables uniquely. Under some (quite specialized) model conditions, the iso- $p$ and iso- $p^{*}$ loci in Figure 1 may coincide such that a given $\left(p, p^{*}\right)$ combination may support a locus of Home-Foreign tariff pairs.
} 
Likewise, any $\left(p, \tilde{p}^{w}\right)$ pair uniquely determines the equilibrium values of $\tau, \tau^{*}$, and $p^{*}$. Figure 1 illustrates, where the three depicted iso-price loci $p p, p^{w} p^{w}$, and $p^{*} p^{*}$ represent respectively the set of tariff pairs that deliver a given Home, world, and Foreign price level.

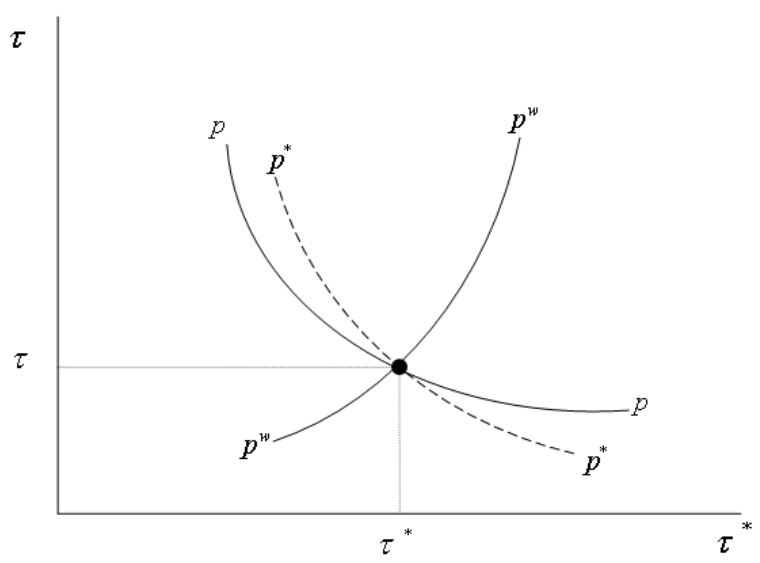

Figure 1: The Bagwell-Staiger Representation of Tariff-Price Relationship.

Bagwell and Staiger (1999) exploit these equilibrium price relationships to establish that any government welfare function that may be written as a function of $\tau$ and $\tau^{*}$ may be recharacterized as a function of equilibrium local and world prices. It is clear that the Home and Foreign government objectives still may be written this way in the presence of international cross-ownership. The influence of international integration lies not in how the government objective functions are written, but in the structure that reasonably may be imposed on them.

Since any pair of the five tariff/price variables pins down the remaining three in equilibrium, it must be true that any pair of Home and world prices pins down the Foreign local price according to the market clearing and balanced budget conditions according to $p^{*} \equiv p^{*}\left(p, \tilde{p}^{w}\right) \cdot{ }^{27}$ Hence, a change in $\tau$ would cause the foreign price to change according to

\footnotetext{
${ }^{27} \mathrm{By}$ the same argument, any pair of Foreign and world prices determines the equilibrium Home price according to $p \equiv\left(p^{*}, \tilde{p}^{w}\right)$.
} 
$\frac{d p^{*}}{d \tau}=\frac{\partial p^{*}\left(p, \tilde{p}^{w}\right)}{\partial \tilde{p}^{w}} \frac{\partial \tilde{p}^{w}}{\partial \tau}+\frac{\partial p^{*}\left(p, \tilde{p}^{w}\right)}{\partial p} \frac{d p}{d \tau}=\frac{1}{\tau^{*}} \frac{\partial \tilde{p}^{w}}{\partial \tau}$. Figure 2 illustrates: increasing $\tau$ while holding $p$ fixed implies changes in both the world price (from $p^{w} p^{w}$ to $p^{w} p^{w \prime}$ ) and the foreign local price (from $p^{*} p^{*}$ to $p^{*} p^{* \prime}$ ). Similarly, the change in $\tau$ holding $\tilde{p}^{w}$ fixed implies movements in both the Home and Foreign prices (from $p p$ to $p p^{\prime}$ and from $p^{*} p^{* \prime}$ to $p^{*} p^{* \prime \prime}$, respectively).

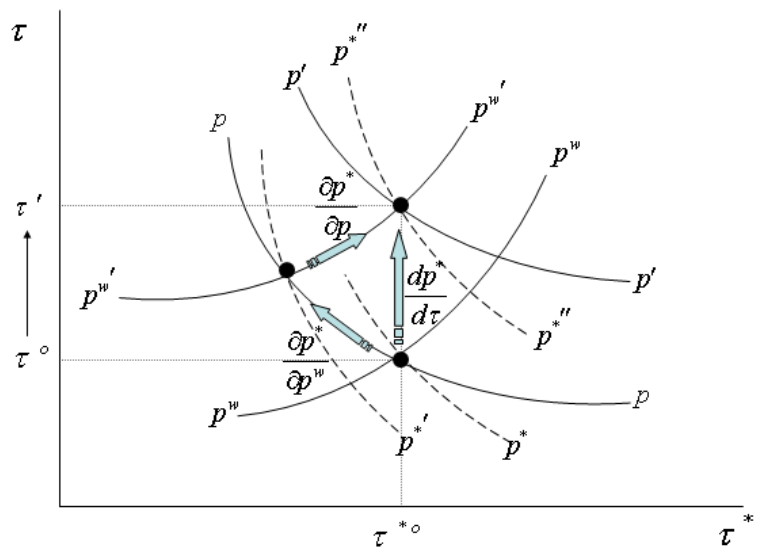

Figure 2: Price Effects of a Tariff Change.

While these changes in the foreign price are of peripheral interest in the Bagwell-Staiger framework, they are of central concern in an environment with international investment. When a country's constituents hold claims on overseas production, national welfare is affected not only by changes in the domestic and world prices, but also by changes in the foreign local price. Decomposing the welfare impact of a tariff change into the three implied price effects clarifies.

$$
\begin{aligned}
\frac{d W}{d \tau} & =\underbrace{\left(\frac{\partial w}{\partial p}+\frac{\partial w}{\partial p^{*}} \frac{\partial p^{*}\left(p, p^{w}\right)}{\partial p}\right)}_{W_{p}} \frac{d p}{d \tau}+\underbrace{\left(\frac{\partial w}{\partial \tilde{p}^{w}}+\frac{\partial w}{\partial p^{*}} \frac{\partial p^{*}\left(p, p^{w}\right)}{\partial p^{w}}\right)}_{W_{\tilde{p}^{*}}^{*}} \frac{\partial \tilde{p}^{w}}{\partial \tau} \\
\frac{d W^{*}}{d \tau^{*}} & =\underbrace{\left(\frac{\partial w^{*}}{\partial p^{*}}+\frac{\partial w^{*}}{\partial p} \frac{\partial p\left(p^{*}, \tilde{p}^{w}\right)}{\partial p^{*}}\right)}_{W_{\tilde{p}}^{*}} \frac{d p^{*}}{d \tau^{*}}+\underbrace{\left(\frac{\partial w^{*}}{\partial p^{w}}+\frac{\partial w^{*}}{\partial p} \frac{\partial p\left(p^{*}, \tilde{p}^{w}\right)}{\partial p^{w}}\right)}_{W^{*}} \frac{\partial \tilde{p}^{w}}{\partial \tau^{*}}
\end{aligned}
$$

In the absence of international ownership, there is no reason for a government to care 
about its trading partner's tariff or local price level apart from its effect on the world price, so that $\frac{\partial w}{\partial p^{*}}=\frac{\partial w^{*}}{\partial p}=0$. Thus, the assumption that holding the local price fixed, both governments benefit from an increase in the terms of trade (i.e. $W_{\tilde{p}^{w}}<0$ and $W_{\tilde{p}^{w}}^{*}>0$ ) constitutes an innocuous (and indeed, the appropriate) assumption for the class of models that Bagwell and Staiger consider. But when countries hold claims on overseas production it is clear that $W_{\tilde{p}^{w}}$ and $W_{\tilde{p}^{w}}^{*}$ may be positive, negative, or zero depending on the pattern of international equity holdings, since changes in the world price (holding the domestic price fixed) affect each country through both the standard terms of trade mechanism and the effect on the returns to foreign investment.

Returning to Bagwell and Staiger's first two observations, it is apparent that if the pattern of international ownership is such that $W_{\tilde{p}^{w}}=W_{\tilde{p}^{w}}^{*}=0$, international integration releases the two countries from the terms of trade driven prisoners' dilemma, so that Nash equilibrium tariffs will be efficient (proof in Appendix 5.3). More generally, to the extent that international integration induces tariff liberalization by reducing the absolute value of $W_{\tilde{p}^{w}}$ and $W_{\tilde{p}^{w}}^{*}$, it can serve as a partial substitute for negotiated tariff reductions. Finally, if the pattern of international investment is such that $W_{\tilde{p}^{w}}>0$ and $W_{\tilde{p}^{w}}^{*}<0$, Nash equilibrium tariffs will be inefficiently low, so that the Pareto improving tariff negotiations would allow countries to cooperatively raise their tariffs.

International integration also implies, contrary to observation (iii), that terms of trade externalities are no longer the sole source of international inefficiency in governments' unilateral tariff choices in the presence of foreign investment. To see this, note that a marginal change in the Home (Foreign) tariff imposes an externality if $W_{\tau}^{*}\left(\tau, \tau^{*}\right) \neq 0\left(W_{\tau^{*}}\left(\tau, \tau^{*}\right) \neq 0\right)$, where:

$$
\begin{aligned}
\frac{d W}{d \tau^{*}} & =\frac{\partial w}{\partial p^{*}} \frac{d p^{*}}{d \tau^{*}}+\left(\frac{\partial w}{\partial p} \tau+\frac{\partial w}{\partial p^{w}}\right) \frac{\partial \tilde{p}^{w}}{\partial \tau^{*}} \\
\frac{d W^{*}}{d \tau} & =\frac{\partial w^{*}}{\partial p} \frac{d p}{d \tau}+\left(\frac{\partial w^{*}}{\partial p^{*}} \frac{1}{\tau^{*}}+\frac{\partial w^{*}}{\partial p^{w}}\right) \frac{\partial \tilde{p}^{w}}{\partial \tau} .
\end{aligned}
$$

In the absence of international cross-ownership, the only effect of a change in $\tau\left(\tau^{*}\right)$ on Foreign (Home) welfare is through the world price. With international cross-ownership, however, the local government can extract rents from foreign investors by manipulating 
the domestic price since international investors' returns are subject to local prices; i.e. $\frac{\partial w^{*}}{\partial p}, \frac{\partial w}{\partial p^{*}} \neq 0$. This internal cost shifting opportunity adds a second source of international inefficiency to countries' unilateral tariff decisions. ${ }^{28}$ Thus, simply making large governments "act small" by ignoring all external price effects of tariff changes ${ }^{29}$ cannot ensure efficient tariffs in the presence of international investment.

Notably, the basic principle of reciprocity - that both countries can gain from mutual tariff changes that hold the world price fixed - still serves as a guide towards efficiency in an environment with international investment. Starting from inefficiently high (low) Nash tariffs, a small mutual tariff reduction (increase) that leaves the world price unchanged provides a Pareto improvement. ${ }^{30}$ Moreover, if Home and Foreign are symmetric, reciprocal tariff changes will lead them all the way to the efficient politically optimal tariffs which balance countries' internal and external interests.

At the same time, however, the formal definition of a reciprocal tariff change must be modified in an environment with international investment. In the Bagwell-Staiger framework, a reciprocal tariff change holds the world price fixed if it implies that the change of each country's import volume equals the value of the change in its export volume. But with international investment, a mutual tariff change will leave the world price unchanged only if the implied shift in each country's import volume is equal to the value of the change in its export volume prorated by any effect of the reciprocal tariff change on net remittances. Intuitively, this modification is required to avoid potential income effects that may follow

\footnotetext{
${ }^{28} \mathrm{An}$ interesting feature of this internal cost shifting externality is that it is not unique to large countries. This contrasts the predominant view that small countries' unilaterally optimal tariffs are internationally efficient so that they need not be included in multilateral trade negotiations.

${ }^{29}$ In the Bagwell-Staiger framework, a government is said to "act small" if it makes its optimal tariff decision under the assumption that $\frac{\partial \tilde{p}^{w}\left(\tau, \tau^{*}\right)}{\partial \tau}=0$. Here, "acting small" is taken to mean that neither the world price, nor the foreign local price is affected by the government's tariff choice. That is, here the Home government would act small by choosing it's tariff so that $\frac{\partial w}{\partial p}=0$, which is not efficient for a large country with holdings overseas. (Recall that $W_{p}=\frac{\partial w}{\partial p}+\frac{\partial w}{\partial p^{*}} \frac{\partial p^{*}}{\partial p}=0$ is efficient.)

${ }^{30}$ Inefficiently high tariffs are characterized by $W_{\tilde{p}^{w}}<0, W_{\tilde{p}^{w}}^{*}>0$, which by (3.9)-(3.10) implies that at Nash equilibrium, $W_{p}<0$ and $W_{p^{*}}^{*}>0$. Thus, a small reduction in $\tau$ and $\tau^{*}$ that holds $\tilde{p}^{w}$ fixed raises both $W$ and $W^{*}$. A parallel argument establishes that a small increase in $\tau$ and $\tau^{*}$ (which holds $\tilde{p}^{w}$ fixed) from inefficiently low Nash tariffs is also Pareto improving.
} 
mutual tariff changes. Although non-trivial, this point is still something of a technicality; further discussion is therefore reserved for the appendix.

\section{Closing Remarks}

This paper identifies the tariff liberalizing potential of international equity integration; an ownership interest in a trading partner's export sector may counter a large country's terms of trade incentive to manipulate world prices, while foreign ownership in the local import sector can erode the local government's willingness to maintain tariffs at the expense of its consumer-constituents. Indeed, a sufficiently integrated pattern of international crossownership may lead a government to set globally efficient tariffs (or even free trade) unilaterally.

By redefining the pecuniary externalities among trading partners, international investment and the concomitant change in the pattern of global ownership suggests careful reevaluation of that the prevailing economic interpretation of the GATT/WTO. Since overseas ownership may decrease (or even eliminate) terms of trade cost shifting among large countries, international integration may effectively substitute in part or full for negotiated tariff liberalization in achieving internationally efficient tariffs. Further, because foreign ownership introduces an internal cost-shifting externality, simply making large countries "act small" is no longer sufficient to ensure internationally efficient tariff regimes in an environment with international investment. Notably, the basic principle of reciprocity remains a powerful guide to efficient tariff negotiations, though its formal definition must be modified somewhat to account for countries' investments abroad in addition to their conventional mercantilist interests.

Returning to the title question, does existing international investment and cross-border ownership make the WTO obsolete? Though theoretically possible, this provocative razor's edge outcome seems unlikely in practice. The important lesson of the paper is instead simply that ownership matters, and that this carries important implications for governments' trade policies and the evolving role of negotiated tariff agreements such as the GATT/WTO. 


\section{References}

Bagwell, K., And R. Staiger (1999): "An Economic Theory of the GATT," American Economic Review, 89(1), 215-48.

(2002): The Economics of the World Trading System. MIT Press, Cambridge, MA.

Bhagwati, J. N., And R. A. Brecher (1980): "National Welfare in an Open Economy in the Presence of Foreign-Owned Factors of Production," Journal of International Economics, 10, 103115.

(1981): "Foreign Ownership and the Theory of Trade and Welfare," Journal of Political Economy, 89(3), 497-511.

Bhagwati, J. N., R. A. Brecher, E. Dinopoulos, and T. Srinivasan (1987): "Quid Pro Quo Foreign Investment and Welfare: A Political-Economy-Theoretic Approach," Journal of Development Economics, 27, 127-138.

Bhagwati, J. N., E. Dinopoulos, And K. Wong (1992): "Quid Pro Quo Foreign Investment," American Economic Review, 82(2), 186-90, Papers and Proceedings.

Blanchard, E. J. (2002): "Liberalizing Trade and Investment Policies: The Expropriation Effect," Mimeo.

(2005a): "Foreign Direct Investment, Endogenous Tariffs, and Preferential Trade Agreements," SSRN working paper 691469.

(2005b): "Trade Imbalances, International Investment, and A Limitation of Lerner's Symmetry Theorem," SSRN working paper 764408 .

Brecher, R. A., And C. Diaz-Alejandro (1977): "Tariffs, Foreign Capital, and Immiserizing Growth," Journal of International Economics, 7, 317-22.

Brecher, R. A., And R. Findlay (1983): "Tariffs, Foreign Capital, and National Welfare with Sector Specific Factors," Journal of International Economics, 14, 277-88.

Devereux, M. B., And K. M. Lee (1999): "Endogenous Trade Policy and the Gains from International Financial Markets," Journal of Monetary Economics, 43, 35-59.

Grossman, G., And E. Helpman (1996): "Foreign Investment with Endogenous Protection," in The Political Economy of Trade Policy, Papers in Honor of Jagdish Bhagwati, ed. by R. Feenstra, and D. Irwin. MIT Press, Cambridge, MA.

Grossman, G. M., And E. Helpman (1994): "Protection For Sale," American Economic Review, 84(4), 833-850.

Johnson, H. G. (1951-52): "Optimum Welfare and Maximum Revenue Tariffs," Review of Economic Studies, 19(1), 28-35.

Konishi, H., K. Saggi, and S. Weber (1999): "Endogenous Trade Policy under Foreign Direct Investment," Journal of International Economics, 49, 289-308.

Maggi, G., ANd A. Rodriguez-Clare (1998): "The Value of Trade Agreements in the Presence of Politica Pressures," Journal of International Economics, 106, 574-601.

Mayer, W. (1981): "Theoretical Considerations on Negotiated Tariff Adjustments," Oxford Economic Papers, 33, 135-53.

NeAry, J. P. (1995): "Factor Mobility and International Trade," Canadian Journal of Economics, Special Issue, S4-S23. 
Neto, D. G. (2002): "Capital Movements and the Political Economy of Trade Policy," Discussion paper, DELTA.

Olarreaga, M. (1999): "Foreign Owned Capital and Endogenous Tariffs," Discussion paper, World Bank Group.

Ornelas, E. (2002): "Rent Dissipation and the Strategic Adoption of Free Trade Areas," Working paper, http://ssrn.com/abstract $=350520$.

Stockman, A., And H. Dellas (1986): "Asset Markets, Tariffs, and Political Risk," Journal of International Economics, 21, 119-213.

Uzawa, H. (1969): "Liberalization of Foreign Investments and the National Economy," Economitsu, 23, 106-22, (in Japanese). 


\section{Appendices}

\subsection{Derivation of the Foreign Optimal Tariff}

The Foreign government chooses its optimal tariff to solve:

$$
\begin{array}{r}
\tau^{* o}=\arg \max _{\tau^{*}} \quad v\left(p^{*}, I^{*}\left(p, p^{w}, p^{*}\right)\right), \\
\text { s.t. } \quad p^{w}=\tilde{p}^{w}\left(\tau, \tau^{*}\right) .
\end{array}
$$

where Foreign income, $I^{*}\left(p, p^{w}, p^{*}\right)$, is defined implicitly by $(2.2)$.

The first order condition is analogous to that for the Home country in (2.10):

$$
V_{\tau^{*}}^{*}=v_{I}^{*}[\underbrace{t^{*} \frac{1}{p^{w}} \frac{d E_{y}}{d \tau^{*}}-E_{y} \frac{\partial \frac{1}{\tilde{p}^{w}}}{\partial \tau^{*}}}_{\text {terms of trade effect }}+\underbrace{-\phi^{*} q_{y}^{*} \frac{d \frac{1}{p^{*}}}{d \tau^{*}}}_{\text {internal effect }}+\underbrace{\phi q_{y} \frac{\partial \frac{1}{\tilde{p}^{w}}}{\partial \tau^{*}}}_{\text {external effect }}]=0
$$

Solving yields the implicit form of the Foreign optimal tariff expression:

$$
\tau^{* o}=1+\frac{1}{\hat{\epsilon}_{y}}\left[1-\frac{\phi q_{y}}{E_{y}}+\frac{\phi^{*} q_{y}^{*}}{E_{y}} \frac{1}{\lambda^{*}}\right]
$$

where $\lambda^{*} \equiv \frac{\frac{\partial \frac{1}{p^{w}}}{\partial \tau^{*}}}{\frac{d p^{*}}{d \tau^{*}}}<0$ by $(2.7)$ and $\hat{\epsilon}_{y} \equiv \epsilon_{y}+\frac{\partial E_{y}(p, I)}{\partial I} \frac{\partial I\left(p, p^{w}, p^{*}\right)}{\partial p^{*}} \frac{1}{p^{w}} \frac{1}{E_{y}} \frac{1}{\lambda^{*}}$, where $\epsilon_{y} \equiv \frac{d E_{y}}{d \frac{1}{p^{w}}} \frac{1}{p^{w}} \frac{1}{E_{y}}$ is Home's elasticity of export supply.

\subsection{Efficient Tariffs}

The set of efficient tariff pairs is defined implicitly by the following tangency condition:

$$
\left.\frac{d \tau}{d \tau^{*}}\right|_{d V=0}=\left.\frac{d \tau}{d \tau^{*}}\right|_{d V^{*}=0} .
$$

From the definition of Home and Foreign indirect utility levels, $V \equiv V\left(\tau, \tau^{*}\right)$ and $V^{*} \equiv$ $V^{*}\left(\tau, \tau^{*}\right)$, this may be rewritten:

$$
\frac{V_{\tau^{*}}}{V_{\tau}}=\frac{V_{\tau^{*}}^{*}}{V_{\tau}^{*}} .
$$


Expanding yields: $:^{31}$

$$
\frac{\left(t p^{w} \frac{d E_{x}^{*}}{d \tau^{*}}-E_{x}^{*} \frac{\partial p^{w}}{\partial \tau^{*}}+\frac{d \Phi}{d \tau^{*}}\right)}{\left(t p^{w} \frac{d E_{x}^{*}}{d \tau}-E_{x}^{*} \frac{\partial p^{w}}{\partial \tau}+\frac{d \Phi}{d \tau}\right)}=\frac{\left(t^{*} p^{*} \frac{d E_{x}^{*}}{d \tau^{*}}-E_{x}^{*} \frac{\partial p^{w}}{\partial \tau^{*}}-\frac{d \Phi}{d \tau^{*}}\right)}{\left(t^{*} p^{*} \frac{d E_{x}^{*}}{d \tau}-E_{x}^{*} \frac{\partial p^{w}}{\partial \tau}-\frac{d \Phi}{d \tau}\right)},
$$

where,

$$
\Phi \equiv \tau^{*} \phi^{*}\left(p^{*} q_{x}^{*}+q_{y}^{*}\right)-\phi\left(p q_{x}+q_{y}\right)
$$

Cross multiplying and combining terms reveals that the set of Pareto efficient $\left(\tau, \tau^{*}\right)$ pairs with cross-ownership is the familiar Mayer (1981) locus:

$$
t p^{w}=-t^{*} p^{*} \Leftrightarrow p=p^{*} \Leftrightarrow \tau=\frac{1}{\tau^{*}} .
$$

This is just as common sense would suggest, since the exchange of property rights should not affect the efficient allocation of resources given identical homothetic preferences.

\subsection{Politically Optimal Tariffs are Efficient}

This appendix proves that politically optimal tariffs $\left(\tau^{P O}, \tau^{* P O}\right)$ (defined as the tariff pair satisfying $W_{p}=0$ and $W_{p^{*}}^{*}=0$ ) are efficient. (Note that this also implies that Nash equilibrium tariffs are efficient if $W_{\tilde{p}^{w}}=W_{\tilde{p}^{w}}^{*}=0$, since if $W_{\tilde{p}^{w}}=W_{\tilde{p}^{w}}^{*}=0$ Nash equilibrium tariffs are politically optimal.)

The following tangency condition defines implicitly the set of efficient tariffs:

$$
\left.\frac{d \tau}{d \tau^{*}}\right|_{d W=0}=\left.\frac{d \tau}{d \tau^{*}}\right|_{d W^{*}=0}
$$

Or,

$$
\frac{W_{\tau^{*}}}{W_{\tau}}=\frac{W_{\tau^{*}}^{*}}{W_{\tau}^{*}}
$$

\footnotetext{
${ }^{31}$ To facilitate algebraic manipulation, it is useful to rewrite the Foreign income expression in (2.2) in units of $y$ measured at the Foreign local price, using the Foreign balanced budget condition in $(2.4): I^{* \prime}=$ $p^{*} q_{x}^{*}+q_{y}^{*}-\Phi+t^{*} p^{*} E_{x}^{*}$. It is then straightforward to confirm that this yields the expressions for $V_{\tau^{*}}^{*}$ and $V_{\tau}^{*}$ in (5.7).
} 
The derivatives of the objective functions may be written:

$$
\begin{aligned}
W_{\tau} & =\underbrace{\left(\frac{\partial w}{\partial p}+\frac{\partial w}{\partial p^{*}} \frac{\partial p^{*}\left(p, \tilde{p}^{w}\right)}{\partial p}\right)}_{W_{p}} \frac{d p}{d \tau}+\underbrace{\left(\frac{\partial w}{\partial p^{w}}+\frac{\partial w}{\partial p^{*}} \frac{\partial p^{*}\left(p, \tilde{p}^{w}\right)}{\partial p^{w}}\right)}_{W_{p^{*}}^{*}} \frac{\partial \tilde{p}^{w}}{\partial \tau} \\
W_{\tau^{*}}^{*} & =\underbrace{\left(\frac{\partial w^{*}}{\partial p^{*}}+\frac{\partial w^{*}}{\partial p} \frac{\partial p\left(p^{*}, \tilde{p}^{w}\right)}{\partial p^{*}}\right)}_{\tilde{p}^{w}} \frac{d p^{*}}{d \tau^{*}}+\underbrace{\left(\frac{\partial w^{*}}{\partial p^{w}}+\frac{\partial w^{*}}{\partial p} \frac{\partial p\left(p^{*}, \tilde{p}^{w}\right)}{\partial p^{w}}\right)}_{W_{\tilde{p}^{w}}^{*}} \frac{\partial \tilde{p}^{w}}{\partial \tau^{*}} \\
W_{\tau^{*}} & =\underbrace{\left(\frac{\partial w}{\partial p}+\frac{\partial w}{\partial p^{*}} \frac{\partial p^{*}\left(p, \tilde{p}^{w}\right)}{\partial p}\right)}_{W_{p^{*}}^{*}} \frac{d p}{d \tau^{*}}+\underbrace{\left(\frac{\partial w}{\partial p^{w}}+\frac{\partial w}{\partial p^{*}} \frac{\partial p^{*}\left(p, \tilde{p}^{w}\right)}{\partial p^{w}}\right)}_{W_{\tilde{p}^{w}}} \frac{\partial \tilde{p}^{w}}{\partial \tau^{*}} \\
W_{\tau}^{*} & =\underbrace{\left(\frac{\partial w^{*}}{\partial p^{*}}+\frac{\partial w^{*}}{\partial p} \frac{\partial p\left(p^{*}, \tilde{p}^{w}\right)}{\partial p^{*}}\right)}_{W_{\tilde{p}}^{*}} \frac{d p^{*}}{d \tau}+\underbrace{\left(\frac{\partial w^{w}}{\partial \tau}\right.}_{\left.\frac{\partial w^{*}}{\partial p^{w}}+\frac{\partial w^{*}}{\partial p} \frac{\partial p\left(p^{*}, \tilde{p}^{w}\right)}{\partial p^{w}}\right)}
\end{aligned}
$$

At $\left(\tau^{P O}, \tau^{* P O}\right), W_{p}=0$ and $W_{p^{*}}^{*}=0$ so that:

$$
\begin{aligned}
W_{\tau} & =W_{\tilde{p}^{w}} \frac{\partial \tilde{p}^{w}}{\partial \tau} \\
W_{\tau^{*}}^{*} & =W_{\tilde{p}^{w}}^{*} \frac{\partial \tilde{p}^{w}}{\partial \tau^{*}} \\
W_{\tau^{*}} & =W_{\tilde{p}^{w}} \frac{\partial \tilde{p}^{w}}{\partial \tau^{*}} \\
W_{\tau}^{*} & =W_{\tilde{p}^{w}}^{*} \frac{\partial \tilde{p}^{w}}{\partial \tau}
\end{aligned}
$$

Substituting (5.16)-(5.19) into (5.11) completes the proof. $\diamond$

\subsection{Reciprocity}

Bagwell and Staiger (1999) (2002) develop the following formal definition of the principle of reciprocity:

Definition 5.1 A set of tariff changes $\Delta \tau=\left(\tau^{1}-\tau^{0}\right)$ and $\Delta \tau^{*}=\left(\tau^{* 1}-\tau^{* 0}\right)$ conforms to the principle of reciprocity if the resulting change in the volume of each country's imports is equal to the value of the change in the volume of its exports; ${ }^{32}$ i.e.

$$
p^{w 0}\left(M_{x}^{1}-M_{x}^{0}\right)=E_{y}^{1}-E_{y}^{0},
$$

\footnotetext{
${ }^{32}$ Note that $(i)$ it does not matter whether imports are valued at $p^{w 0}$ or $p^{w 1}$, and $(i i)$ if (5.20) holds, the analogous condition holds for Foreign by market clearing.
} 
where $p^{w i}=p^{w}\left(\tau^{i}, \tau^{* i}\right), M_{x}^{i}=M_{x}\left(p^{i}\left(\tau^{i}, p^{w i}\right), p^{w i}\right)$ and $E_{y}^{i}=E_{y}\left(p^{i}\left(\tau^{i}, p^{w i}\right), p^{w i}\right)$ for $i \in$ $\{0,1\}$.

From Home's balanced budget condition in (2.3): $p^{w 0} M_{x}^{0}=E_{y}^{0}+\Phi^{0}$ and $p^{w 1} M_{x}^{1}=$ $E_{y}^{1}+\Phi^{1}$. Substituting into (5.20) and rearranging yields:

$$
\begin{aligned}
\left(p^{w 1}-p^{w 0}\right) M_{x}^{1} & =\Phi^{1}-\Phi^{0} \text { or } \\
\Delta p^{w} M_{x}^{1} & =\Delta \Phi
\end{aligned}
$$

which implies that a reciprocal tariff change (one that offers equal market access concessions in each country, as defined above) leaves the world price unchanged if and only if it also leaves net remittances unchanged. Recall that the Bagwell-Staiger framework assumes balanced trade, so that $\Phi^{0}, \Phi^{1} \equiv 0 \rightarrow \Delta \Phi=0$, which implies that any reciprocal tariff change must leave the world price unchanged. But here net remittances depend on the world price (recall that $\left.\Phi \equiv \phi^{*}\left(p^{w} q_{x}^{*}+\tau^{*} q_{y}^{*}\right)-\phi\left(\tau p^{w} q_{x}+q_{y}\right)\right)$, so that $\Delta \Phi$ depends on $\Delta p^{w}$. It is therefore no longer obvious that a reciprocal tariff change will leave the world price fixed. And indeed, as demonstrated below, this will hold only under very special (and apparently arbitrary) conditions.

Starting from any inefficient tariff pair (for which $p \neq p^{*}$ ), a reciprocal tariff change will affect the world price only if it causes one country's budget set to increase more than the other's, since preferences are identical and homothetic. The national budget sets for Home and Foreign may be written respectively:

$$
\begin{aligned}
B & \equiv p^{w} q_{x}+q_{y}+\Phi \\
B^{*} & \equiv p^{w} q_{x}^{*}+q_{y}^{*}-\Phi .
\end{aligned}
$$

Thus, starting from any inefficient tariff pair a reciprocal tariff change will leave $p^{w}$ fixed if and only if $\Delta B-\left.\Delta B^{*}\right|_{\Delta p^{w}=0}=0$, where:

$$
\begin{aligned}
\Delta B & \equiv p^{w} \Delta q_{x}+\Delta q_{y}+\Delta \Phi \\
\Delta B^{*} & \equiv p^{w} \Delta q_{x}^{*}+\Delta q_{y}^{*}-\Delta \Phi .
\end{aligned}
$$

If $\left.\Delta \Phi\right|_{\Delta p^{w}=0}=0$ :

$$
\Delta B-\Delta B^{*}=p^{w} \Delta q_{x}+\Delta q_{y}-p^{w} \Delta q_{x}^{*}+\Delta q_{y}^{*},
$$


which defines implicitly the relationship between $\Delta \tau$ and $\Delta \tau^{*}$ that would have to hold in order for $\Delta p^{w}=0$. But since net remittances are endogenous, $\left.\Delta \Phi\right|_{\Delta p^{w}=0}=0$ also defines implicitly the relationship between $\Delta \tau$ and $\Delta \tau^{*}$ that is required to leave net remittances unchanged given a fixed world price. In general there is no reason to expect the reciprocal tariff relationships implied by $\Delta B-\left.\Delta B^{*}\right|_{\Delta p^{w}=0}=0$ and $\left.\Delta \Phi\right|_{\Delta p^{w}=0}=0$ to coincide. There is no reason to expect the current definition of reciprocity to fix the world price in the presence of international investment.

To see this more clearly, consider the effect of a marginal reciprocal tariff change on net remittances and the difference between the Home and Foreign budget sets, holding the world price fixed. It is quite clear that the implied reciprocal tariff relationship, $\left.\frac{d \tau}{d \tau^{*}}\right|_{d \Phi, d p^{w}=0}$ will in general differ from $\left.\frac{d \tau}{d \tau^{*}}\right|_{d\left(B-B^{*}\right), d p^{w}=0}$, since:

$$
\begin{aligned}
\left.d \Phi\right|_{d p^{w}=0} & =\phi^{*} q_{y}^{*} d \tau^{*}-\phi p^{w} q_{x} d \tau=0 \\
\left.d\left(B-B^{*}\right)\right|_{d p^{w}=0} & =-t^{*} p^{*} \frac{d q_{x}^{*}}{d p^{*}} \frac{d p^{*}}{d \tau^{*}} d \tau^{*}-t p^{w} \frac{d q_{x}}{d p} \frac{d p}{d \tau} d \tau=0 .
\end{aligned}
$$

A new definition of reciprocity is therefore needed to permit governments to change their tariffs reciprocally while holding the world price fixed. The following modified definition of reciprocity is designed to serve exactly such a role:

Definition 5.2 A set of tariff changes $\Delta \tau=\left(\tau^{1}-\tau^{0}\right)$ and $\Delta \tau^{*}=\left(\tau^{* 1}-\tau^{* 0}\right)$ conforms to the modified principle of reciprocity if the resulting change in the volume of each country's imports is equal to the value of the change in the volume of its exports prorated by any induced change in net remittances; i.e.

$$
p^{w 0}\left(M_{x}^{1}-M_{x}^{0}\right)=\left(E_{y}^{1}-E_{y}^{0}\right)+\left(\Phi^{1}-\Phi^{0}\right)
$$

It is clear that mutual changes in the Home and Foreign tariffs that conform to this modified principle of reciprocity leave the world price fixed, since together with Home's balanced budget condition, (5.30) requires:

$$
\Delta p^{w} M_{x}^{1}=0 \Rightarrow \Delta p^{w}=0
$$


Note that the pattern of international ownership is perfectly symmetric such that $\left.\Delta \Phi\right|_{\Delta p^{w}=0}=0$, the modified definition of reciprocity collapses to Definition 5.1. More generally, Definition (5.2) requires that any reciprocal tariff change that causes net Foreign to Home remittances to increase (decrease) by $\Delta \Phi$, must induce a change in the trade volume of $x$ that is exactly $\Delta \Phi$ greater than (less than) the change in the trade volume of $y$. 


\section{CESifo Working Paper Series}

(for full list see www.cesifo-group.de)

1673 Michael Rauber and Heinrich W. Ursprung, Evaluation of Researchers: A Life Cycle Analysis of German Academic Economists, February 2006

1674 Ernesto Reuben and Frans van Winden, Reciprocity and Emotions when Reciprocators Know each other, February 2006

1675 Assar Lindbeck and Mats Persson, A Model of Income Insurance and Social Norms, February 2006

1676 Horst Raff, Michael Ryan and Frank Staehler, Asset Ownership and Foreign-Market Entry, February 2006

1677 Miguel Portela, Rob Alessie and Coen Teulings, Measurement Error in Education and Growth Regressions, February 2006

1678 Andreas Haufler, Alexander Klemm and Guttorm Schjelderup, Globalisation and the Mix of Wage and Profit Taxes, February 2006

1679 Kurt R. Brekke and Lars Sørgard, Public versus Private Health Care in a National Health Service, March 2006

1680 Dominik Grafenhofer, Christian Jaag, Christian Keuschnigg and Mirela Keuschnigg, Probabilistic Aging, March 2006

1681 Wladimir Raymond, Pierre Mohnen, Franz Palm and Sybrand Schim van der Loeff, Persistence of Innovation in Dutch Manufacturing: Is it Spurious?, March 2006

1682 Andrea Colciago, V. Anton Muscatelli, Tiziano Ropele and Patrizio Tirelli, The Role of Fiscal Policy in a Monetary Union: Are National Automatic Stabilizers Effective?, March 2006

1683 Mario Jametti and Thomas von Ungern-Sternberg, Risk Selection in Natural Disaster Insurance - the Case of France, March 2006

1684 Ken Sennewald and Klaus Waelde, "Itô's Lemma“ and the Bellman Equation for Poisson Processes: An Applied View, March 2006

1685 Ernesto Reuben and Frans van Winden, Negative Reciprocity and the Interaction of Emotions and Fairness Norms, March 2006

1686 Françoise Forges, The Ex Ante Incentive Compatible Core in Exchange Economies with and without Indivisibilities, March 2006

1687 Assar Lindbeck, Mårten Palme and Mats Persson, Job Security and Work Absence: Evidence from a Natural Experiment, March 2006 
1688 Sebastian Buhai and Coen Teulings, Tenure Profiles and Efficient Separation in a Stochastic Productivity Model, March 2006

1689 Gebhard Kirchgaessner and Silika Prohl, Sustainability of Swiss Fiscal Policy, March 2006

1690 A. Lans Bovenberg and Peter Birch Sørensen, Optimal Taxation and Social Insurance in a Lifetime Perspective, March 2006

1691 Moritz Schularick and Thomas M. Steger, Does Financial Integration Spur Economic Growth? New Evidence from the First Era of Financial Globalization, March 2006

1692 Burkhard Heer and Alfred Maussner, Business Cycle Dynamics of a New Keynesian Overlapping Generations Model with Progressive Income Taxation, March 2006

1693 Jarko Fidrmuc and Iikka Korhonen, Meta-Analysis of the Business Cycle Correlation between the Euro Area and the CEECs, March 2006

1694 Steffen Henzel and Timo Wollmershaeuser, The New Keynesian Phillips Curve and the Role of Expectations: Evidence from the Ifo World Economic Survey, March 2006

1695 Yin-Wong Cheung, An Empirical Model of Daily Highs and Lows, March 2006

1696 Scott Alan Carson, African-American and White Living Standards in the $19^{\text {th }}$ Century American South: A Biological Comparison, March 2006

1697 Helge Berger, Optimal Central Bank Design: Benchmarks for the ECB, March 2006

1698 Vjollca Sadiraj, Jan Tuinstra and Frans van Winden, On the Size of the Winning Set in the Presence of Interest Groups, April 2006

1699 Martin Gassebner, Michael Lamla and Jan-Egbert Sturm, Economic, Demographic and Political Determinants of Pollution Reassessed: A Sensitivity Analysis, April 2006

1700 Louis N. Christofides and Amy Chen Peng, Major Provisions of Labour Contracts and their Theoretical Coherence, April 2006

1701 Christian Groth, Karl-Josef Koch and Thomas M. Steger, Rethinking the Concept of Long-Run Economic Growth, April 2006

1702 Dirk Schindler and Guttorm Schjelderup, Company Tax Reform in Europe and its Effect on Collusive Behavior, April 2006

1703 Françoise Forges and Enrico Minelli, Afriat's Theorem for General Budget Sets, April 2006

1704 M. Hashem Pesaran, Ron P. Smith, Takashi Yamagata and Liudmyla Hvozdyk, Pairwise Tests of Purchasing Power Parity Using Aggregate and Disaggregate Price Measures, April 2006 
1705 Piero Gottardi and Felix Kubler, Social Security and Risk Sharing, April 2006

1706 Giacomo Corneo and Christina M. Fong, What's the Monetary Value of Distributive Justice?, April 2006

1707 Andreas Knabe, Ronnie Schoeb and Joachim Weimann, Marginal Employment Subsidization: A New Concept and a Reappraisal, April 2006

1708 Hans-Werner Sinn, The Pathological Export Boom and the Bazaar Effect - How to Solve the German Puzzle, April 2006

1709 Helge Berger and Stephan Danninger, The Employment Effects of Labor and Product Markets Deregulation and their Implications for Structural Reform, May 2006

1710 Michael Ehrmann and Marcel Fratzscher, Global Financial Transmission of Monetary Policy Shocks, May 2006

1711 Carsten Eckel and Hartmut Egger, Wage Bargaining and Multinational Firms in General Equilibrium, May 2006

1712 Mathias Hoffmann, Proprietary Income, Entrepreneurial Risk, and the Predictability of U.S. Stock Returns, May 2006

1713 Marc-Andreas Muendler and Sascha O. Becker, Margins of Multinational Labor Substitution, May 2006

1714 Surajeet Chakravarty and W. Bentley MacLeod, Construction Contracts (or "How to Get the Right Building at the Right Price?”), May 2006

1715 David Encaoua and Yassine Lefouili, Choosing Intellectual Protection: Imitation, Patent Strength and Licensing, May 2006

1716 Chris van Klaveren, Bernard van Praag and Henriette Maassen van den Brink, Empirical Estimation Results of a Collective Household Time Allocation Model, May 2006

1717 Paul De Grauwe and Agnieszka Markiewicz, Learning to Forecast the Exchange Rate: Two Competing Approaches, May 2006

1718 Sijbren Cnossen, Tobacco Taxation in the European Union, May 2006

1719 Marcel Gérard and Fernando Ruiz, Interjurisdictional Competition for Higher Education and Firms, May 2006

1720 Ronald McKinnon and Gunther Schnabl, China's Exchange Rate and International Adjustment in Wages, Prices, and Interest Rates: Japan Déjà Vu?, May 2006

1721 Paolo M. Panteghini, The Capital Structure of Multinational Companies under Tax Competition, May 2006 
1722 Johannes Becker, Clemens Fuest and Thomas Hemmelgarn, Corporate Tax Reform and Foreign Direct Investment in Germany - Evidence from Firm-Level Data, May 2006

1723 Christian Kleiber, Martin Sexauer and Klaus Waelde, Bequests, Taxation and the Distribution of Wealth in a General Equilibrium Model, May 2006

1724 Axel Dreher and Jan-Egbert Sturm, Do IMF and World Bank Influence Voting in the UN General Assembly?, May 2006

1725 Swapan K. Bhattacharya and Biswa N. Bhattacharyay, Prospects of Regional Cooperation in Trade, Investment and Finance in Asia: An Empirical Analysis on BIMSTEC Countries and Japan, May 2006

1726 Philippe Choné and Laurent Linnemer, Assessing Horizontal Mergers under Uncertain Efficiency Gains, May 2006

1727 Daniel Houser and Thomas Stratmann, Selling Favors in the Lab: Experiments on Campaign Finance Reform, May 2006

1728 E. Maarten Bosker, Steven Brakman, Harry Garretsen and Marc Schramm, A Century of Shocks: The Evolution of the German City Size Distribution 1925 - 1999, May 2006

1729 Clive Bell and Hans Gersbach, Growth and Enduring Epidemic Diseases, May 2006

1730 W. Bentley MacLeod, Reputations, Relationships and the Enforcement of Incomplete Contracts, May 2006

1731 Jan K. Brueckner and Ricardo Flores-Fillol, Airline Schedule Competition: ProductQuality Choice in a Duopoly Model, May 2006

1732 Kerstin Bernoth and Guntram B. Wolff, Fool the Markets? Creative Accounting, Fiscal Transparency and Sovereign Risk Premia, May 2006

1733 Emmanuelle Auriol and Pierre M. Picard, Government Outsourcing: Public Contracting with Private Monopoly, May 2006

1734 Guglielmo Maria Caporale and Luis A. Gil-Alana, Modelling Structural Breaks in the US, UK and Japanese Unemployment Rates, May 2006

1735 Emily J. Blanchard, Reevaluating the Role of Trade Agreements: Does Investment Globalization Make the WTO Obsolete?, May 2006 